\title{
GAMBARAN KEJADIAN DEPRESI LANSIA DI PANTI WREDHA DHARMA BHAKTI SURAKARTA
}

\author{
${ }^{1}$ Dewi Wulandari, ${ }^{2}$ Estiningtyas \\ Stikes Mitra Husada Karanganyar \\ mujahidfiisabiilillah@gmail.com ${ }^{1)}$ \\ bidanesti@gmail.com ${ }^{2}$
}

\begin{abstract}
ABSTRAK
Lansia sangat rentan terhadap gangguan kesehatan, termasuk depresi yang disebabkan oleh stres dalam menghadapi perubahan-perubahan kehidupan seperti pensiun, penyakit atau ketidakmampuan fisik, penempatan dalam panti wreda, kematian pasangan, dan kebutuhan untuk merawat pasangan yang kesehatannya menurun. Tujuan penelitian ini adalah untuk mengetahui gambaran kejadian depresi lansia di panti wredha Dharma Bhakti Surakarta. Penelitian ini merupakan penelitian deskriptif. Penelitian dilakukan pada bulan Mei - Juli 2019. Populasi penelitian ini adalah lansia yang berada di Panti Wredha Dharma Bhakti Surakarta. Pengambilan sampel dengan menggunakan total sampling dan didapatkan sampel sejumlah 73 responden. Teknik pengumpulan data dilakukan melalui pengisian kuesioner Geriatric Depression Scale-30. Hasil penelitian menunjukkan bahwa sebagian besar lansia $(65,8 \%)$ tidak mengalami depresi. Sebanyak 30,1\% responden mengalami depresi ringan dan 4,1\% mengalami depresi berat. Responden yang mengalami depresi sebagian besar berusia 60-74 tahun (15 lansia), berjenis kelamin perempuan(18 lansia), mempunyai riwayat pekerjaan sebagai buruh (9 lansia), tidak tamat SD (13 lansia), berstatus sebagai janda (12 lansia), dan mempunyai kemampuan fungsional mandiri (20 lansia). Simpulan: Kejadian depresi di Panti Wredha Dharma Bhakti Surakarta mencapai 34\% (sebanyak 25 lansia dari 73 responden).
\end{abstract}

Kata kunci: depresi, lansia, panti wredha

\begin{abstract}
The elderly are very susceptible to health problems, including depression caused by stress in the face of life changes such as retirement, illness or physical disability, placement in nursing homes, partner deaths, and the need to care for couples whose health is declining. The purpose of this study was to determine the description of the incidence of depression in elderly at Dharma Bhakti Surakarta nursing homes. This research was descriptive research. The study was conducted in May - July 2019. The population of this research was the elderly who are in Dharma Bhakti Surakarta nursing homes. Sampling used total sampling and obtained a sample of 73 respondents. Data collection techniques were carried out through filling the Geriatric Depression Scale-30 questionnaire. The results showed that most of the elderly (65.8\%) did not experience depression. As many as $30.1 \%$ of respondents experienced mild depression and $4.1 \%$ experienced severe depression. Most respondents who were depressed were aged 60-74 years (15 elderly), female (18 elderly), had a history of working as a laborer (9 elderly), not graduating from elementary school (13 elderly), being widowed (12 elderly), and has independent functional abilities (20 elderly). Conclusion: The incidence of depression in Surakarta Wedha Dharma Bhakti Orphanage reached 34\% (as many as 25 elderly from 73 respondents).
\end{abstract}

Keywords: depression, elderly, nursing home

\section{PENDAHULUAN}

Lansia mengalami perubahan dan kemunduran baik secara fisik maupun psikis pada proses menua. Perubahan psikis yang terjadi pada lansia yaitu menurunnya gairah dan minat terhadap penampilan, serta peningkatan sensitifitas emosional seperti mudah tersinggung, cemas, dan depresi. Penurunan kondisi fisik yang terjadi sangat mempengaruhi kondisi psikis pada lansia. Pengaruh ini disebabkan oleh berubahnya penampilan, menurunnya fungsi panca indra dan mengakibatkan lansia merasa rendah diri, mudah tersinggung, kesepian dan merasa tidak berguna lagi. Masalah tersebut akan memicu terjadinya masalah kesehatan mental pada lansia, yaitu depresi. Depresi merupakan gangguan alam perasaan yang berat dan ditandai dengan gangguan fungsi fisik dan fungsi sosial yang hebat, lama dan menetap pada individu tersebut (Yosep, 2009).

Sejumlah faktor resiko psikososial juga melibatkan lansia kepada gangguan mental. Faktor resiko tersebut adalah hilangnya peranan sosial, hilangnya ekonomi, kematian teman atau sanak saudaranya, penurunan kesehatan, peningkatan isolasi karena hilangnya interaksi sosial, keterbatasan finansial, dan penuruann fungsi kognitif (Kusumowardani and Puspitosari, 2014). 
Faktor demografi seperti usia, jenis kelamin, status pernikahan merupakan beberapa faktor yang berpengaruh terhadap kejadian depresi pada lansia (Riyadi, 2009). Lansia yang berada di panti memiliki tingkat depresi yang lebih tinggi daripada lansia yang berada dirumah (Pae. 2017). Hal ini didukung oleh hasil penelitian yang dilakukan oleh Saputri (2011) yang menunjukkan bahwa depresi pada lansia yang tinggal di Panti Wreda berada pada kategori tinggi, dan dukungan sosialnya berada pada kategori rendah.

Perasaan kesepian akan muncul saat jauh dari keluarga karena tidak ada lagi orang-orang yang selama ini hidup bersama serta berbagi segala sesuatu. Ketika perasaan kesepian muncul maka stessor meningkat dan akan menimbulkan depresi. Jika depresi dibiarkan dan tidak ditangani dengan benar dapat membuat lansia berkeinginan untuk mencederai diri sendiri atau bahkan mengakhiri hidup. Hasil studi menunjukkan dukungan sosial bagi lansia sangat penting, karena dukungan sosial yang baik telah terbukti menurunkan depresi parental dan bertindak sebagai suatu pelindung bagi lansia. Semakin tinggi dukungan sosial yang diterima oleh lansia yang tinggal di panti, semakin rendah depresi yang dialami oleh lansia (Widianingrum, 2016).

Adanya keragaman tempat tinggal lansia memberikan pengaruh yang berbeda dalam kejadian depresi. Beberapa penelitian menunjukkan bahwa perbedaan tempat tinggal lansia menjadi faktor prediktor independen untuk terjadinya depresi. Penelitian yang dilakukan oleh Masturin di Kelurahan Cacaban Kota Magelang didapatkan hasil bahwa prevalensi depresi lebih banyak ditemukan pada lansia yang tinggal di panti wreda $(30 \%)$ daripada lansia yang tinggal di komunitas $(15,5 \%)$ (Kurniawati, 2013).

Penelitian Monika (2014) menunjukkan bahwa Dari hasil penelitian lansia yang tinggal di Panti Wredha Dharma Bhakti lebih banyak mengalami depresi dibandingkan dengan lansia yang tinggal bersama keluarga di Kelurahan Pajang. Dari 31 lansia yang tinggal di panti Wredha Dharma Bhakti Surakarta terdapat sebanyak 28 orang $(90 \%)$ yang mengalami depresi. Tujuan penelitian ini adalah untuk mendeskripsikan kejadian dan tingkat depresi lansia di Panti Wredha Dharma Bhakti Surakarta.

\section{METODE}

Penelitian ini merupakan penelitian deskriptif, yaitu jenis penelitian yang tujuannya untuk menyajikan gambaran lengkap mengenai setting sosial atau dimaksudkan untuk eksplorasi dan klarifikasi mengenai suatu fenomena atau kenyataan sosial. Penelitian ini akan dilakukan di Panti Wredha Dharma Bhakti Surakarta pada bulan Mei - Juli 2019. Populasi pada

penelitian ini adalah lansia yang berada di Panti Wredha Dharma Bhakti Surakarta. Teknik Sampling dengan menggunakan total sampling dan didapatkan sebanyak 73 responden. Teknik pengumpulan data dilakukan melalui pengisian kuesioner Geriatric Depression Scale-30. Pengolahan data hasil penelitian meliputi proses editing, coding, scoring, dan tabulating.

\section{HASIL DAN PEMBAHASAN}

Panti Wredha Dharma Bhakti merupakan tempat untuk merawat orang yang telah lanjut usia atau jompo. Panti Wredha ini terletak di Jalan Dr. Radjiman No. 620 Kelurahan Pajang, Kecamatan Laweyan, Kota Surakarta, Provinsi Jawa Tengah. Panti Wredha ini didirikan di atas tanah seluas 3.500 meter persegi. Gedung Panti Wredha Dharma Bhakti Surakarta terlihat bersih dan nyaman. Panti ini memiliki 32 kamar dalam bangunan berjajar dihuni oleh 75 lansia. Pengambilan data penelitian dilakukan terhadap 73 responden.

Tabel 1. Karakteristik responden

\begin{tabular}{cccc}
\hline \multicolumn{2}{c}{ Karakteristik } & $\begin{array}{c}\text { Freku } \\
\text { ensi }\end{array}$ & $\begin{array}{c}\text { Prosent } \\
\text { ase (\%) }\end{array}$ \\
\hline Usia & 60-74 tahun & 45 & 61.6 \\
& 75-90 tahun & 28 & 38.4 \\
Jenis & perempuan & 43 & 58.9 \\
Kelamin & laki-laki & 30 & 41.1 \\
Riwayat & wiraswasta & 18 & 24.7 \\
Pekerjaan & petani & 5 & 6.8 \\
& Buruh & 29 & 39.7 \\
& IRT & 13 & 17.8 \\
& Tidak & 8 & 11.0 \\
Pendidikan & bekerja & & \\
Terakhir & Tidak & 38 & 52.1 \\
& sekolah & & \\
& SD & 14 & 19.2 \\
& SMP & 11 & 15.1 \\
Status & SMA & 10 & 13.7 \\
Pernikahan & Menikah & 31 & 42.5 \\
& Duda & 10 & 13.7 \\
& Janda & 24 & 32.9 \\
& Tidak & 8 & 11.0 \\
& menikah & & \\
\hline \multicolumn{7}{c}{ Total } & 73 & 100 \\
\hline
\end{tabular}

Tabel 1 menunjukkan dari 73 responden terdapat 45 lansia $(61,6 \%)$ berusia $60-74$ tahun, sisanya sebanyak 28 lansia $(38,4 \%)$ berusia $75-90$ tahun. Sebagian besar lansia $(58,9 \%)$ berjenis kelamin perempuan, sisanya sebanyak 30 lansia $(41,1 \%)$ berjenis kelamin laki-laki. Lansia yang memiliki riwayat pekerjaan sebagai wiraswasta sebanyak 18 orang $(24,7 \%)$, sebagai petani sebanyak 5 orang $(6,8 \%)$, sebagai buruh sebanyak 
29 orang $(39,7 \%)$, sebagai ibu rumah tangga sebanyak 13 orang $(17,8 \%)$, sisanya sebanyak 8 lansia $(11 \%)$ tidak bekerja.

Lansia yang memiliki pendidikan terakhir SD sebanyak 14 orang (19,2\%), SMP sebanyak 11 orang $(15,1 \%)$, dan SMA sebanyak 10 orang $(13,7 \%)$. Sebagian besar lansia (38 lansia) tidak tamat SD. Lansia yang masih memiliki suami/istri sebanyak 31 orang $(42,5 \%)$. Lansia yang berstatus duda sebanyak 10 orang $(13,7 \%)$, janda sebanyak 24 orang $(32,9 \%)$, dan tidak menikah sebanyak 8 orang $(11 \%)$.

Responden dalam penelitian ini sebanyak $61,6 \%$ berusia $60-74$ tahun dan $38,4 \%$ berusia $75-$ 90 tahun. Perkembangan proyeksi usia harapan hidup di Indonesia dari tahun 2010 hingga tahun 2035 mengalami peningkatan dari tahun ke tahun atau memiliki tren positif. Peningkatan usia harapan hidup akan menyebabkan proporsi penduduk lanjut usia semakin besar. Usia harapan hidup di Indonesia pada awal tahun 2010 mencapai 70,1 tahun, dan diproyeksikan oleh BPS usia harapan hidup di Indonesia pada tahun 2035 mencapai tingkat usia 72,2 tahun. Usia harapan hidup di kota Surakarta pada awal tahun 2010 mencapai 76,85 tahun dan pada tahun 2035 mencapai tingkat usia 72,2 tahun 77,06 (Sulthon dan Purwanti, 2019).

Tabel 2. Penyakit yang diderita responden satu tahun terakhir

\begin{tabular}{cccc}
\hline Jenis Penyakit & & Frekuensi & $\begin{array}{c}\text { Prosentas } \\
\text { e (\%) }\end{array}$ \\
\cline { 1 - 1 } Tidak ada & & 24 & 32.9 \\
Hipertensi & & 11 & 15.1 \\
Penyakit sendi & & 17 & 23.3 \\
Stroke & 5 & 6.8 \\
Gangguan & 5 & 6.8 \\
pernafasan & & \\
DM & 3 & 4.1 \\
Hipotensi & 2 & 2.7 \\
Masalah kulit & 4 & 5.5 \\
Penyakit jantung & 2 & 2.7 \\
\hline Total & 73 & 100.0 \\
\hline
\end{tabular}

Tabel 2 menunjukkan bahwa penyakit atau masalah kesehatan yang dialami lansia selama satu tahun terakhir adalah penyakit sendi $(23,3 \%)$, hipertensi $(15,1 \%)$, stroke $(6,8 \%)$, gangguan pernafasan $(6,8 \%)$, masalah kulit $(5,5 \%)$, Diabetes Mellitus $(4,1 \%)$, hipotensi $(2,7 \%)$, dan penyakit jantung (27\%). Lansia yang tidak mengalami masalah kesehatan serius sebanyak 24 lansia $(32,9 \%)$

Lansia merupakan salah satu kelompok atau populasi berisiko (population at risk) yang semakin meningkat jumlahnya. Allender, Rector, dan Warner (2014) mengatakan bahwa populasi berisiko (population at risk) adalah kumpulan orang-orang yang masalah kesehatannya memiliki kemungkinan akan berkembang lebih buruk karena adanya faktor-faktor risiko yang memengaruhi. Menurut, Stanhope dan Lancaster (2016) lansia sebagai populasi berisiko ini memiliki tiga karakteristik risiko kesehatan yaitu, risiko biologi termasuk risiko terkait usia, risiko sosial dan lingkungan serta risiko perilaku atau gaya hidup.

Lansia identik dengan berbagai penurunan status kesehatan terutama status kesehatan fisik. Berbagai teori tentang proses menua menunjukkan hal yang sama. Status kesehatan lansia yang menurun seiring dengan bertambahnya usia akan memengaruhi kualitas hidup lansia. Bertambahnya usia akan diiringi dengan timbulnya berbagai penyakit, penurunan fungsi tubuh, keseimbangan tubuh dan risiko jatuh (Setyorini et al., 2019).

Tabel 3 Fungsi penglihatan dan pendengaran Responde

\begin{tabular}{cccc}
\hline \multicolumn{2}{c}{ Fungsi Penginderaan } & $\begin{array}{c}\text { Frekuen } \\
\text { si }\end{array}$ & $\begin{array}{c}\text { Prosentas } \\
\text { e }(\%)\end{array}$ \\
\hline $\begin{array}{c}\text { Pengliha } \\
\text { tan }\end{array}$ & baik & 44 & 60.3 \\
& & 29 & 39.7 \\
$\begin{array}{c}\text { Pendeng } \\
\text { aran }\end{array}$ & benurun & 57 & 78.1 \\
& menurun & 16 & 21.9 \\
\hline & Total & 73 & 100.0 \\
\hline
\end{tabular}

Tabel 3 menunjukkan bahwa sebagian besar lansia masih mempunyai penglihatan yang berfungsi dengan baik (60,3\%). Sebagian besar responden $(78,1 \%)$ juga memiliki pendengaran yang berfungsi dengan baik). Sebagian lansia mengalami penurunan penglihatan (29 lansia), dan sebagian lansia (16 orang) mengalami penurunan pendengaran.

Hasil penelitian Astuti (2018) menunjukkan bahwa kondisi lansia yang mengalami gangguan fungsional menetap seperti kondisi rambut yang mudah rontok, mata yang kabur, gangguan pada retina, kondisi impotensi psikogenik berisiko mengalami depresi. Kondisi tersebut disebabkan oleh suatu perubahan kondisi yang menetap dan mengganggu dalam pemenuhan kebutuhan Lansia. Beberapa penyakit kronis yang menjadi faktor risiko meningkatnya kerentanan seseorang terhadap depresi yaitu stroke, hilangnya fungsi pendengaran, hilangnya fungsi penglihatan, penyakit jantung, penyakit kronis paru, penyakit arthritis, hipertensi dan diabetes (Usman dan Wijayati, 2017). 
Tabel 4. Masalah yang menjadi beban psikologis responden

\begin{tabular}{ccc}
\hline Jenis & Frekuensi & $\begin{array}{c}\text { Prosentase } \\
(\%)\end{array}$ \\
\cline { 2 - 2 } Masalah & & 53.4 \\
tidak ada & 39 & 27.4 \\
masalah & 20 & \\
keluarga & & 13.7 \\
masalah & 10 & \\
kesehatan & & \\
$\begin{array}{c}\text { fisik } \\
\text { masalah }\end{array}$ & 4 & 5.5 \\
keuangan & & 100.0 \\
\hline Total & 73 & \\
\hline
\end{tabular}

Tabel 4 menunjukkan bahwa 53,4\% responden tidak memiliki masalah yang bermakna dalam kehidupannya. Sebanyak $27,4 \%$ responden mengatakan mempunyai masalah keluarga yang menjadi beban psikologis, $13,7 \%$ responden mengungkapkan masalah kesehatan fisik, dan 5,5\% mengungkapkan masalah perekonomian.

Faktor-faktor yang menjadi penyebab depresi dibagi menjadi faktor biologi, faktor genetik, dan faktor psikososial. Menurut Freud dalam teori psikodinamikanya, penyebab depresi adalah kehilangan objek yang dicintai. Ada sejumlah faktor psikososial yang diprediksi sebagai penyebab gangguan mental pada lanjut usia yang pada umumnya berhubungan dengan kehilangan. Faktor psikososial tersebut adalah hilangnya peranan sosial, hilangnya otonomi, kematian teman atau sanak saudara, penurunan kesehatan, peningkatan isolasi diri, keterbatasan finansial dan penurunan fungsi kognitif. Faktor psikososial yang mempengaruhi depresi meliputi peristiwa kehidupan dan stressor lingkungan, kepribadian, psikodinamika, kegagalan yang berulang, teori kognitif dan dukungan sosial (Kaplan and Sadock, 2008).

Tabel 5. Kemampuan fungsional responden

\begin{tabular}{ccc}
\hline $\begin{array}{c}\text { Kemampuan } \\
\text { fungsional }\end{array}$ & Frekuensi & $\begin{array}{c}\text { Prosentase } \\
(\mathbf{\%})\end{array}$ \\
\hline mandiri & 58 & 79.5 \\
Ketergantungan & 4 & 5.5 \\
$\begin{array}{c}\text { ringan } \\
\text { Ketergantungan } \\
\text { moderat }\end{array}$ & 7 & 9.6 \\
Ketergantungan berat & 4 & 5.5 \\
\hline Total & 73 & 100.0 \\
\hline
\end{tabular}

Tabel 5 menunjukkan bahwa kemampuan fungsional sebagian besar responden $(79,5 \%)$ adalah mandiri, sebanyak $9,6 \%$ responden mengalami ketergantungan ringan, 5,5\% mengalami ketergantungan moderat, dan 5,5\% mengalami ketergantungan berat. Hasil penelitian Cahyono (2013) menyatakan bahwa terdapat hubungan antara tingkat kemandirian lansia dalam melakukan aktivitas sehari-hari dengan tingkat kecemasan. Seseorang lansia dengan tingkat kecemasan yang tinggi cenderung mengalami ketergantungan dalam melakukan aktivitas seharihari.

Kondisi kesehatan yang baik memungkinkan lansia melakukan aktivitas apa saja tanpa memerlukan bantuan atau sedikit bergantung pada orang lain. Adanya gangguan kesehatan dapat mempengaruhi kemandirian pada lansia. Hal ini didukung dengan hasil penelitian Seran (2016) yang menyatakan bahwa ada hubungan antara nyeri gout arthritis dengan kemandirian lansia. Lansia yang mengalami nyeri cenderung memerlukan bantuan dalam melakukan aktivitas seharihari mereka karena terganggu dengan nyeri yang dirasakannya. Hasil penelitian Sampelan et al. (2015) juga menunjukkan bahwa terdapat hubungan yang sangat nyata antara dukungan keluarga dengan kemandirian lansia.

Tingkat depresi berhubungan dengan kemandirian Activity Daily Living (ADL) pada lansia. Semakin berat tingkat depresi maka lansia tersebut akan mengalami ketergantungan dalam melakukan aktivitas sehari-hari, dan sebaliknya apabila seorang lansia tidak mengalami depresi akan dapat melakukan aktivitas sehari-hari secara mandiri. Hal tersebut dapat terjadi karena lansia yang mempunyai kondisi kesehatan yang baik, baik kesehatan fisik maupun mental maka lansia dapat melakukan aktivitas seharihari secara mandiri (Mulyaningsih dan Arum, 2017).

Tabel 6. Tingkat depresi responden

\begin{tabular}{ccc}
\hline $\begin{array}{c}\text { Tingkat } \\
\text { Depresi }\end{array}$ & Frekuensi & Prosentase (\%) \\
\hline Normal & 48 & 65.8 \\
$\begin{array}{c}\text { Depresi } \\
\text { ringan }\end{array}$ & 22 & 30.1 \\
Depresi & 3 & 4.1 \\
Berat & & \\
\hline Total & 73 & 100.0 \\
\hline
\end{tabular}

Tabel 6 menunjukkan bahwa sebagian besar lansia $(65,8 \%)$ tidak mengalami depresi. Sebanyak $30,1 \%$ responden mengalami depresi ringan dan 4,1\% mengalami depresi berat.

Lansia adalah kelompok lanjut usia yang rentan mengalami depresi. Depresi lansia disebabkan oleh kurangnya kemampuan beradaptasi terhadap perubahan pada diri akibat kemunduran fisik, mental dan sosial yang dialami. Keparahan gangguan depresi lansia dikategorikan menjadi tiga tingkatan yaitu tidak depresi, depresi ringan dan depresi sedang/berat (Parasari dan Lestari, 2015). Berdasarkan World Health 
Organization (WHO), prevalensi keseluruhan kejadian depresi pada lansia secara umum bervariasi antara $10-20 \%$, hal ini juga tergantung pada situasi budaya di masing-masing daerah di dunia (Bodhare et al., 2013).

Tabel 7. Tingkat depresi responden berdasarkan karakteristik responden

\begin{tabular}{|c|c|c|c|c|}
\hline \multicolumn{2}{|c|}{ Karakteristik } & \multicolumn{3}{|c|}{ Tingkat Depresi } \\
\hline & & Normal & Depresi ringan & Depresi Berat \\
\hline \multirow[t]{2}{*}{ Usia } & $60-74$ & 30 & 13 & 2 \\
\hline & $75-90$ & 18 & 9 & 1 \\
\hline \multirow[t]{2}{*}{ Jenis kelamin } & perempuan & 25 & 15 & 3 \\
\hline & laki-laki & 23 & 7 & 0 \\
\hline \multirow[t]{5}{*}{ Riwayat Pekerjaan } & wiraswasta & 14 & 1 & 3 \\
\hline & petani & 3 & 2 & 0 \\
\hline & Buruh & 20 & 9 & 0 \\
\hline & IRT & 7 & 6 & 0 \\
\hline & Tidak bekerja & 4 & 4 & 0 \\
\hline \multirow[t]{5}{*}{ Riwayat Pekerjaan } & wiraswasta & 14 & 1 & 3 \\
\hline & petani & 3 & 2 & 0 \\
\hline & Buruh & 20 & 9 & 0 \\
\hline & IRT & 7 & 6 & 0 \\
\hline & Tidak bekerja & 4 & 4 & 0 \\
\hline \multirow[t]{4}{*}{ Pendidikan terakhir } & Tidak sekolah & 25 & 10 & 3 \\
\hline & SD & 8 & 6 & 0 \\
\hline & SMP & 6 & 5 & 0 \\
\hline & SMA & 9 & 1 & 0 \\
\hline \multirow[t]{4}{*}{ Status Pernikahan } & Menikah & 22 & 9 & 0 \\
\hline & Duda & 9 & 1 & 0 \\
\hline & Janda & 12 & 9 & 3 \\
\hline & Tidak menikah & 5 & 3 & 0 \\
\hline \multirow[t]{9}{*}{ Penyakit Fisik } & Tidak ada & 19 & 3 & 2 \\
\hline & Hipertensi & 7 & 4 & 0 \\
\hline & Penyakit sendi & 10 & 7 & 0 \\
\hline & Stroke & 3 & 2 & 0 \\
\hline & Gangguan pernafasan & 1 & 4 & 0 \\
\hline & DM & 2 & 1 & 0 \\
\hline & Hipotensi & 2 & 0 & 0 \\
\hline & Masalah kulit & 4 & 0 & 0 \\
\hline & Penyakit jantung & 0 & 1 & 1 \\
\hline \multirow[t]{2}{*}{ Fungsi penglihatan } & baik & 31 & 12 & 1 \\
\hline & menurun & 17 & 10 & 2 \\
\hline \multirow[t]{2}{*}{ Fungsi pendengaran } & baik & 40 & 14 & 3 \\
\hline & menurun & 8 & 8 & 0 \\
\hline \multirow{4}{*}{$\begin{array}{l}\text { Masalah beban } \\
\text { psikologis }\end{array}$} & tidak ada & 27 & 10 & 2 \\
\hline & masalah keluarga & 14 & 5 & 1 \\
\hline & masalah kesehatan fisik & 4 & 6 & 0 \\
\hline & masalah keuangan & 3 & 1 & 0 \\
\hline \multirow[t]{4}{*}{ Kemampuan fungsional } & mandiri & 38 & 18 & 2 \\
\hline & Ketergantungan ringan & 2 & 2 & 0 \\
\hline & Ketergantungan moderat & 5 & 1 & 1 \\
\hline & Ketergantungan berat & 3 & 1 & 0 \\
\hline
\end{tabular}


Tabel 7 menunjukkan bahwa responden yang mengalami depresi sebagian besar berusia 6074 tahun (sebanyak 15 responden). Sedangkan responden yang mengalami depresi berusia 75-90 tahun sebanyak 10 lansia. Penelitian lain menyebutkan bahwa dari kelompok sampel yang mengalami depresi, persentase depresi tertinggi terjadi pada kelompok usia 75-90 tahun dengan sebaran proporsi depresi ringan 25,0\% dan depresi berat 11,5\% (WWPSR et al., 2015). Sebagian besar responden yang mengalami depresi berjenis kelamin perempuan, yaitu sebanyak 18 lansia. Sedangkan yang berjenis kelamin laki-laki sebanyak 7 lansia. Insiden depresi di Amerika Serikat diketahui lebih dari $12 \%$ pada laki-laki dan $20 \%$ pada perempuan (Belmaker et al., 2008).

Responden yang mengalami depresi mempunyai riwayat pekerjaan sebagai buruh (9 lansia), ibu rumah tangga (6 lansia), tidak bekerja (4 lansia), wiraswata sebanyak 4 lansia yang 3 di antaranya depresi berat, dan petani (2 lansia). Responden yang mengalami depresi sebagian besar berpendidikan tidak sekolah (tidak tamat SD), yaitu sebanyak 13 lansia, dan 3 di antaranya mengalamai depresi berat. Sebanyak 6 lansia yang depresi berpendidikan SD, 5 lansia depresi berpendidikan SMP, dan 1 lansia depresi berpendidikan SMA. Sebanyak 12 lansia yang depresi berstatus sebagai janda, dan 3 di antaranya mengalami depresi berat. Sebanyak 9 responden depresi berstatus menikah, 3 lansia depresi berstatus tidak menikah, dan 1 lansia depresi berstatus duda.

Sebanyak 2 responden yang mengalami depresi berat tidak mempunyai riwayat penyakit, sedangkan 1 responden yang depresi berat mempunyai riwayat penyakit jantung. Responden yang mengalami depresi ringan memiliki penyakit sendi sebanyak 7 orang, 4 responden dengan hipertensi, 4 orang dengan gangguan pernafasan, 3 orang tidak memiliki riwayat penyakit, 2 orang menderita stroke, 1 orang memiliki DM, dan 1 orang mengalami penyakit jantung. Fungsi penglihatan responden yang mengalami depresi masih berfungsi baik sebanyak 13 orang dan yang sudah mengalami penurunan sebanyak 12 orang. Fungsi pendengaran responden yang mengalami depresi masih berfungsi dengan baik sebanyak 17 orang, di mana 3 di antaranya depresi berat. Sedangkan yang fungsi pendengarannya mengalami penurunan sebanyak 8 orang.

Sebanyak 12 responden yang mengalami depresi (2 di antaranya depresi berat) tidak mempunyai masalah yang menjadi beban psikologis. Terdapat 6 responden depresi yang mempunyai masalah keluarga, 6 orang memiliki masalah kesehatan fisik, dan 1 orang mempunyai masalah keuangan. Sebanyak 20 responden yang mengalami depresi (2 di antaranya) mempunyai kemampuan fungsional mandiri. Terdapat 2 lansia depresi yang mengalami ketergantungan ringan, 2 lansia depresi (1 di antaranya depresi berat) mengalami ketergantungan moderat, dan 1 lansia depresi mengalami ketergantungan berat.

Hasil penelitian ini sejalan dengan teori yang menyatakan bahwa penyebab depresi menurut Stuart (2009) adalah akumulasi ketidakpuasan, frustasi, kritikan pada diri sendiri tentang kejadian hidup sehari-hari tanpa adanya dukungan hal positif, stres dalam pekerjaan dan keluarga serta kehilangan. Penyebab depresi tidak hanya disebabkan oleh satu faktor saja, akan tetapi dapat saling berinteraksi dengan faktor yang lain, sehingga munculnya depresi.

Menurut Miller (2012), salah satu faktor risiko terjadinya depresi pada Lansia adalah gangguan fungsional menetap seperti akibat kelumpuhan, gangguan penglihatan, gangguan pergerakan, ketidakmampuan dalam melakukan aktifitas sehari-hari akibat intoleransi tubuh. Gangguan fungsional tubuh lansia yang menetap membuat lansia merasa tidak berdaya dan putus asa. Lansia merasa tidak ada gunanyahidup di dunia dengan kondisinya tersebut.

Lansia merasa tidak produktif dan tidak berguna bagi orang disekitar, bahkan merasa menjadi beban bagi orang lain. Perubahan kondisi kesehatan lansia yang membuat ketidakmampuannya lagi untuk bekerja keras, mudah lelah, penurunan penglihatan dan kondisi kecacatan karena amputasi merupakan gangguan fungsional menetap yang ditemukan pada lansia di Wilayah Kerja Puskesmas Jekan Raya (Astuti et al., 2018)

\section{KESIMPULAN}

Angka kejadian depresi pada lansia di Panti Wredha Dharma Bhakti Surakarta mencapai 34\%. Dari 73 responden didapatkan lansia yang mengalami depresi sebanyak 25 orang, di mana 22 lansia depresi ringan dan 3 lansia depresi berat.

\section{SARAN}

Diharapkan adanya petugas kesehatan yang menjadi staf di Panti Wredha terkait masalah penuaan pada lansia yang rentan menimbulkan masalah kesehatan fisik maupun masalah psikologis. Terlebih lansia yang tinggal di panti memiliki riwayat historis yang kurang menyenangkan dalam pengalaman hidupnya.

\section{DAFTAR PUSTAKA}

Allender, J.A., Rector, C., \& Warner, K.D. 2014. Community and Public Health Nursing Promoting the Public's Health (8thEd.). Philadelphia: Lippincott Williams \& Wilkins

Astuti, A. D., Sulistyowati, R., \& Natalansyah, N. 2018. Gangguan Fungsional Menetap Berpengaruh Pada Risiko Depresi Lansia 
DM Di Wilayah Kerja Puskesmas Jekan Raya Kota Palangka Raya. Jurnal Kesehatan Manarang, 3(2), 54-57.

Bodhare TN, Kaushal V, Venkatesh K, Kumar MA. 2013. Prevalence And Risk Factors Of Depression Among Elderly Population In Rural Area. Perspective in Medical Research. India, 1(1): 11-15.

Cahyono. 2013. Hubungan Tingkat Kemandirian Lansia dalam Melakukan Aktivitas Seharihari dengan Tingkat Kecemasan. Jurnal AKP. Volume 8, Nomor 1.

Kaplan, H.I. \& Sadock, B.J. 2008. Sinopsis Psikiatri Jilid 2. Jakarta: Binarupa Aksara.

Kurniawati, Vetty and Ngestiningsih, Dwi. 2013. Kejadian dan Tingkat Depresi pada Lanjut Usia: Studi Perbandingan di Panti Wreda Pemerintah dan Panti Wreda Swasta. Undergraduate thesis, Faculty of Medicine Diponegoro University.

Kusumowardani, Andreany and Puspitosari, A. 2014. Hubungan Antara Tingkat Depresi Lansia dengan Interaksi Sosial Lansia Di Desa Sobokerto Kecamatan Ngemplak Boyolali. Jurnal Terpadu Ilmu Kesehatan, Volume 3, No 2, November 2014, hlm 106-214.

Miller, C.A. 2012. Nursing Care of Older Adult: Theory and Practice. Philadelphia: Lippincott Williams \& Wilkins.

Monika, A. D. 2014. Perbedaan Tingkat Depresi Antara Lansia Yang Tinggal Di Panti Wredha Dharma Bhakti Dan Yang Bersama Keluarga Di Kelurahan Pajang (Doctoral dissertation, Universitas Muhammadiyah Surakarta).

Mulyaningsih, M., \& Arum, R. T. S. 2017. Tingkat Depresi Mempengaruhi Kemandirian Activity Daily Living (ADL) Lansia. Gaster: Jurnal Kesehatan, 15(2), 121-131.

Pae, Kristina. 2017. Perbedaan Tingkat Depresi Pada Lansia Yang Tinggal Di Panti Dan Yang Tinggal Di Rumah Bersama Keluarga. Jurnal Ners LENTERA Vol.5 No.1 Maret 2017.

Parasari, G. A. T., \& Lestari, M. D. 2015. Hubungan dukungan sosial keluarga dengan tingkat depresi pada lansia di Kelurahan Sading. Jurnal Psikologi Udayana, 2(1), 68-77.

Riyadi, S. 2009. Asuhan Keperawatan Jiwa. Yogyakarta: Graha Ilmu.
Sampelan, Kundre, Lolong. 2015.Hubungan Dukungan Keluarga Dengan Kemandirian Lansia Dalam Pemenuhan Aktivitas Sehari-hari di Desa Batu Kecamatan Likupang Selatan Kabupaten Minahasa Utara. E-Jurnal Keperawatan. Volume 3, Nomor 2.

Saputri MAW, Indrawati ES. 2011. Hubungan antara Dukungan Sosial dengan Depresi pada Lanjut Usia yang Tinggal di Panti Wreda Wening Wardoyo Jawa Tengah. Jurnal Psikologi Undip.

Seran. 2016. Hubungan Antara Nyeri Gout Arthritis Dengan Kemandirian Lansia di Puskesmas Towuntu Timur Kecamatan Pasan Kabupaten Minahasa Tenggara. Jurnal Keperawatan. Volume 4, Nomor 1.

Setyorini, D., E Suciati, I., Trisna, T., E Supriyadi, B., D Wicaksono, R., D Tanika, M., \& M Nilamsari, D. 2019. Peningkatan Kualitas Hidup Lanjut Usia (Lansia) Di Kampung Penumping Rw 03 Dengan Latihan Fisik. http://eprints.uad.ac.id/16156/1/Artikel\%20K KN.pdf.

Stanhope, M., \& Lancaster, J. 2016. Public Health Nursing Population Centered Health Care in the Community (9thEd.). Missouri: Elsevier.

Stuart, G.W. 2009. Principles and Practice of Psychiatric Nursing. St. Louis: Mosby.

Sulthon, H. A., \& Purwanti, E. Y. 2019. Analisis Pengaruh Sosial Ekonomi Terhadap Partisipasi Kerja Penduduk Lanjut Usia Di Kota Semarang (Doctoral dissertation, Fakultas Ekonomika dan Bisnis).

Usman, R. D., \& Wijayati, F. 2017. Identifikasi Kondisi Depresi Lansia Di Panti Sosial Tresna Werdha Minaula Kendari (Doctoral dissertation, Poltekkes Kemenkes Kendari).

Widianingrum, S. 2016. Gambaran Umum Karakteristik Lansia Dengan Depresi di Panti Wilayah Kota Semarang. Skripsi. Universitas Diponegoro Semarang.

WWPSR, I. A. B., Ratep, N., \& Westa, W. 2015. Gambaran Faktor-Faktor Yang Mempengaruhi Tingkat Depresi Pada Lanjut Usia Di Wilayah Kerja Puskesmas Kubu II Januari-Februari 2014. E-Jurnal Medika Udayana, 4 (1), 1-14.

Yosep I. 2009. Keperawatan Jiwa (Edisi Revisi). Bandung. PT Refika Aditama. 